\title{
A Glance over the Last Decade of Literature about Animal Sperm Banks
}

\section{Isabel Casas*}

Biotechnology of Animal Reproduction (TechnoSperm), Department of Biology, University of Girona, Campus Montilivi, s/n, 17071 Girona, Catalonia, Spain

\section{Commentary}

Global population growth threatens the diversity of AnGRs (Animal Genetic Resources), which is critical for livestock and wild animal viability, food safety and rural development. The AnGRs are also fundamental to preserve the natural heritage for the future [1-3]. In this sense, animal sperm banks are tools to secure the genetic diversity [4]. A retrospective analysis of the bibliography in this area was performed to unveil the most recurrent topics in animal sperm bank research in the last decade.

A total of 692 published journal articles that related to the animal (non-human) sperm repositories from 2004 to 2014 were screened using the Pubmed $^{\oplus}$ searching engine. Descriptive statistics were implemented using SPSS $^{\circledR}$ v15.0.1 software after classifying the journal articles according to four different parameters: country, species, research goal, and preservation method.

Results showed that five countries (Australia, Brazil, Japan, Spain and USA) authored the $53.14 \%$ of the articles about animal sperm banks that were sampled. Also, the $63 \%$ of the articles focused on the domestic species, and certain research topics in these articles were tested more recurrently than others. These were the optimization of the preservation protocol and the test of the sperm viability; these topics accounted $70.58 \%$ of the articles in the sample.

Conventional cryopreservation has been the main preservation model adopted in the last ten years $(90.08 \%$ of publications in the sample). It consists in rapid or slow immersion of sperm in liquid nitrogen before packing sperm into a straw, bag, tube or vial $[5,6]$. Despite of such predominance, alternative models were also tested for storage of sperm at low temperatures, understanding low temperatures as those below refrigeration $\left(15^{\circ} \mathrm{C}\right)$ : pellet cryopreservation (equilibrating in dimethylamide for few minutes, and then dropping raw sperm into liquid nitrogen), cryomicroscopy, directional freezing, suspension of sperm in EGTA-Tris-HCl buffered solution, unique freezing technology, storage in ultra-freezer at $-80^{\circ} \mathrm{C}$ or $-150^{\circ} \mathrm{C}$, freezing without cryoprotectant or using special freezing device, drying (freeze-drying, evaporative /convective /heat /vacuum drying, and spin drying), cooling $\left(4-5^{\circ} \mathrm{C}\right)$ and vitrification (freezing at high cryoprotectant concentrations) [7-10].

The contribution of new and more optimized techniques to the conservation of AnGRs would not be possible without the establishment of global consortiums and collaborative networks (e.g. the Frozen Zoo, the Frozen Ark Project, Reef Recovery, WAZA, etc.) [11-13], whose main challenge consists in scaling up practices in animal sperm banks to the organizational level of plant and human repositories.

\section{References}

1. Zonabend E, Okeyo AM, Ojango JMK, Hoffmann I, Moyo S, et al. (2013) Infrastructure for sustainable use of animal genetic resources in Southern and Eastern Africa. Anim Gen Res 53: 79-93.

2. http://www.fao.org/ag/againfo/programmes/en/genetics/Guidelines.html

3. http://www.cbd.int/gbo4

4. Holt WV (2001) Germplasm cryopreservation in elephants and wild ungulates. In: Cryobanking the genetic resource: wildlife conservation for the future? Holt WV, Watson PF (eds.). Taylor and Francis, London.

5. Watson PF, Holt VW (2001) Cryobanking the genetic resource: wildlife conservation for the future? Taylor and Francis, London

6. Casas I, Flores E (2013) Gene banking: the freezing strategy. In: Boar reproduction: fundamentals and new biotechnological trends. Bonet (eds.), Springer-Verlag, Berlin Heidelberg.

7. Pursel VG, Johnson LA (1975) Freezing of boar spermatozoa: fertilizing capacity with concentrated semen and a new thawing procedure. J Anim Sci 40: 99-102.

8. Westendorf P, Richter L, Treu H (1975) Deep freezing of boar sperm. Laboratory and insemination results using the Hülsenberger straw method. Dtsch Tierarztl Wochenschr 82: 261-267.

9. Wakayama T, Yanagimachi R (1998) Development of normal mice from oocytes injected with freeze-dried spermatozoa. Nat Biotechnol 16: 639-641.

10. Tucker MJ, Liebermann J (2007) Vitrification in assisted reproduction: a user's manual and trouble-shooting guide. Informa Healthcare, London.

11. http://www.frozenark.org

12. http://acceleratingscience.com/biobanking/the-frozen-zoo/

13. http://www.waza.org/en/site/home

*Corresponding author: Isabel Casas, Biotechnology of Animal Reproduction (TechnoSperm), Department of Biology, University of Girona, Campus Montilivi, s/n, 17071 Girona, Catalonia, Spain, Tel: +34 9724180 46; E-mail: isabel.casas@hotmail.com

Received June 05, 2015; Accepted July 23, 2015; Published July 25, 2015

Citation: Casas I (2015) A Glance over the Last Decade of Literature about Animal Sperm Banks. Single Cell Biol 4: 116. doi:10.4172/2168-9431.1000116

Copyright: (c) 2015 Casas I. This is an open-access article distributed under the terms of the Creative Commons Attribution License, which permits unrestricted use, distribution, and reproduction in any medium, provided the original author and source are credited. 